\title{
Immunohistochemistry contribution to the diagnosis of prostate cancer
}

\author{
Contribuição da imuno-histoquímica no diagnóstico do câncer de próstata
}

Míriam de Fátima Brasil Engelman; Fiorita Gonzales Lopes Mundim²; Rogério Mendes Grande3; Lucas Ribeiro Borges de Carvalho4; Felipe Moreira Ridolfi ${ }^{4}$

\begin{tabular}{|c|c|}
\hline words & \\
\hline $\begin{array}{l}\text { Prostate } \\
\text { Immunohistochemistry } \\
\text { Needle biopsy } \\
\text { Adenocarcinoma }\end{array}$ & $\begin{array}{l}\text { Introduction: Efforts for the identification of prostate cancer in the initial clinical and pathological } \\
\text { stages led to an increase in the number of biopsies, sometimes making the histological diagnosis of } \\
\text { adenocarcinoma difficult. This is due to the presence of minimal carcinoma or atypical glands suspicious } \\
\text { for carcinoma, also known as atypical small acinar proliferation (ASAP). In these cases, the use of } \\
\text { immunohistochemistry (IHC) has become a common practice in laboratories of pathology. Objectives: } \\
\text { The aims of this study were to assess the incidence of diagnoses of ASAP and minimal adenocarcinoma } \\
\text { in two laboratories of pathology and to evaluate the contribution of IHC and repeat biopsy to the } \\
\text { diagnosis of prostate cancer. Methods: We reviewed } 641 \text { sets of modified sextant needle biopsies of } \\
\text { the prostate performed in two laboratories of pathology between January } 2005 \text { and December } 2010 \text {. } \\
\text { IHC using } 34 \beta E 12 \text { and p63 antibodies was performed on } 35 \text { of } 73 \text { ( } 11.38 \% \text { ) cases diagnosed as ASAP } \\
\text { and on } 7(1.1 \%) \text { cases diagnosed as minimal adenocarcinoma. Results: The incidence of ASAP diagnosis } \\
\text { was } 11.38 \%(n=73) \text {. IHC was performed in } 35 \text { of the } 73 \text { ASAP cases and provided conclusive results } \\
\text { in } 31 \text { cases ( } 88.57 \%) \text {, resulting in a final diagnosis of adenocarcinoma in } 19 \text { patients ( } 54.28 \% \text { ), benign } \\
\text { lesions in } 12 \text { patients ( } 3428 \% \text { ); only } 4 \text { ( } 11.42 \% \text { ) were inconclusive. Conclusion: The results suggest } \\
\text { that IHC should be routinely used in evaluation of borderline biopsies and in ASAP cases. IHC strongly } \\
\text { contributes to the diagnosis of prostate cancer. }\end{array}$ \\
\hline
\end{tabular}

resumo

Introdução: Os esforços de detecção precoce do câncer de próstata, identificados em fases clínicas e patológicas iniciais, levou ao aumento no número de biópsias e, por vezes, indefinição do diagnóstico histológico de adenocarcinoma devido à presença de carcinomas mínimos ou alterações pseudoneoplásicas, como proliferação atípica de pequenos ácinos (PAPA). Nesses casos, o uso da imuno-histoquímica (IMH) para evidenciar a presença de células basais tornou-se uma prática comum em laboratórios de patologia. Objetivos: O presente estudo visa a avaliar a incidência de PAPA e de adenocarcinoma mínimo em dois laboratórios de patologia do interior, bem como avaliar a contribuição da IMH e da rebiópsia no diagnóstico do câncer de próstata. Métodos: Foram revistas 641 biópsias de próstata por agulha realizadas entre janeiro de 2005 e dezembro de 2010. Dos 73 casos diagnosticados como PAPA (11,38\%), 35 foram submetidos ao exame imuno-histoquímico, usando anticorpos anti-34ßE12 e p63, assim como sete casos diagnosticados como adenocarcinoma mínimo (1,1\%). Resultados: Os resultados mostraram que a técnica foi conclusiva em 31 casos (88,57\%), com diagnóstico final de adenocarcinoma em 19 pacientes (54,28\%); 12 (34,28\%) com lesões benignas; e apenas quatro $(11,42 \%)$ inconclusivos (PAPA). Conclusão: Os resultados sugerem que IMH deve ser rotineiramente usada em biópsias limítrofes e casos de PAPA, pois contribui significativamente para o diagnóstico de câncer de próstata. unitermos

\section{Próstata}

Immuno-histoquímica

Biópsia por agulha

Adenocarcinoma

1. Doutora em Ciências da Saúde; professora titular de Patologia do curso de Medicina da Faculdade de Ciências da Saúde da Universidade do Vale do Sapucaí (Univás).

2. Mestra em Ciências da Saúde; professora de Patologia da Faculdade de Ciências da Saúde da Univás.

3. Mestre em Ciências da Saúde; professor de Patologia da Faculdade de Ciências da Saúde da Univás.

4. Acadêmico do curso de Medicina da Univás. 


\section{Introduction}

Prostate cancer is one of the most prevalent cancers among men $^{(20)}$. Early detection efforts, including the use of prostate-specific antigen (PSA)-based screening and digital rectal examination, have resulted in the identification of lower stage and smaller volume carcinomas (minimal adenocarcinoma) of the prostate and sometimes in inconclusive histological diagnosis of adenocarcinoma due to the presence of pseudoneoplastic changes, such as atypical small acinar proliferation (ASAP), prostatic atrophy, and basal cell hyperplasia ${ }^{(14)}$.

ASAP is a diagnostic category that has been used in cases where there is insufficient evidence for the diagnosis of cancer. In such cases, the pathologist should be conservative and classify the lesions as "suspicious but not diagnostic of adenocarcinoma"(14). In this paper, we use ASAP to encompass all suspicious lesions, non diagnostic of adenocarcinoma.

The histopathological diagnosis of adenocarcinoma is based on the microscopic appearance of sections stained with hematoxylin and eosin. Major criteria include an infiltrative glandular growth pattern, absence of basal cells, and nuclear atypia in the form of nucleomegaly and nucleolomegaly. Minor criteria include intraluminal wispy blue mucin, pink amorphous secretions, mitotic figures, intraluminal crystalloids, adjacent high grade prostatic intraepithelial neoplasia, amphophilic cytoplasm, and nuclear hyperchromasia.

In difficult cases, basal cell absence may be confirmed by immunohistochemical stains for high molecular weight cytokeratin (marked with antibody $34 \beta \mathrm{E} 12$ ) or p63, which are basal cell markers ${ }^{(10,11,22,31,32)}$. In these cases, immunohistochemistry $(\mathrm{IHC})$ may show the presence or absence of a basal cell layer in a small focus of atypical glands, helping to establish a benign or malignant diagnosis, that is, to distinguish invasive adenocarcinoma from benign lesions that maintain the basal cell layer.

IHC may reduce the number of inconclusive results ${ }^{(1,22)}$ and the need for repeat biopsy, preventing potential complications, such as hematuria, rectal bleeding, infections, and acute urinary retention ${ }^{(4)}$. It is also important to note that the need for repeat biopsy may delay cancer diagnosis and treatment ${ }^{(10)}$.

The aim of this study was to assess the incidence of diagnoses of ASAP and minimal adenocarcinoma in two laboratories of surgical pathology and evaluate the contribution of IHC and repeat biopsy to the diagnosis of prostate cancer.

\section{Methods}

A total of 641 sets of modified sextant needle biopsies of the prostate from patients with a mean age of 66.75 \pm 9.0 years (range, $36-86$ years) were examined in two laboratories of surgical pathology, one public and one private, between January 1, 2006 and December 31, 2010. Progressive increase in PSA levels was the most common reason for biopsy.

We evaluated histopathological diagnoses made on sections stained with hematoxylin and eosin (HE). Based on the final diagnosis, the cases were divided into three categories: malignant, benign and ASAP lesions.

IHC using the antibodies high-molecular-weight cytokeratin (clone 34ßBE12; Dako) at a dilution of 1:7200 and anti-p63 (clone 4A4; Neomarkers) at a dilution of 1:4000 was performed on recut sections in 35 cases. After deparaffinization and rehydration, the slides were immersed in $10 \mathrm{mM}$ citrate buffer $(\mathrm{pH} 6)$ for $40 \mathrm{~min}$ in steamer at $92^{\circ} \mathrm{C}$ for antigen retrieval. The antibodies were incubated overnight at $4^{\circ} \mathrm{C}$, and the biotin-labeled secondary antibody was incubated for 30 minutes at room temperature. The streptavidin-labeled streptavidin-biotin amplification method (Dako K0679) was carried out for 30 minutes followed by peroxidase/diaminobenzidine substrate/chromagen. The slides were counterstained with hematoxylin.

Data was analyzed using descriptive statistics, according to the type of diagnosis (benign, malignant, or ASAP lesions). The prevalences of diagnoses of ASAP and minimal carcinoma in the series were calculated and compared with the respective results of immunohistochemical staining for basal cells and repeat biopsy results.

\section{Results}

\section{Evaluation of the initial series}

From the 641 cases evaluated in the series, 346 (53.98\%) were diagnosed as benign, $222(34.53 \%)$ as malignant, and $73(11.38 \%)$ as ASAP lesions (Figure 1). The overall mean age of the study patients was $66.75 \pm$ 9.0 years; patients diagnosed with benign, malignant, and ASAP lesions had a mean age of $65.28 \pm 8.86$ years, 69.10 \pm 8.81 years, and $66.5 \pm 8.91$ years, respectively. 


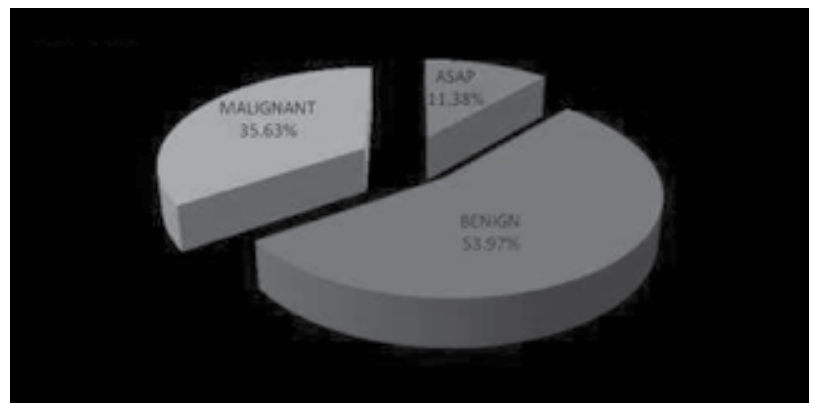

Figure 1 - Diagnosis from prostate needle biopsies $(n=641)$ performed by two laboratories of surgical pathology over a period of five consecutive years ASAP: atypical small acinar proliferation.

\section{Evaluation of ASAP cases reported in the initial series}

The percentage of ASAP cases reported by the public laboratory of pathology was $12.15 \%$ and by the private laboratory was $10.61 \%$. In the public laboratory, there was an increase in the percentage of ASAP diagnosis between 2006 and 2008, followed by a gradual decrease over the years (Figure 2).

\section{ASAP cases from the initial series tested by IHC}

IHC was performed in 35 of the 73 ASAP cases (Figures 3, 4 and 5), and provided conclusive results in 31 cases $(88.57 \%)$, resulting in a final diagnosis of adenocarcinoma in 19 patients (54.28\%) and benign lesions in 12 patients (34 28\%); only four (11.42\%) findings were inconclusive. From the 19 cases with a final diagnosis of adenocarcinoma, 18 had a Gleason score $3+3=6$ and one had a Gleason score $4+4=8$, indicating that most tumors had an intermediate grade of malignancy. IHC results and Gleason scores are shown in Table 1 and Figure 6.

\section{ASAP and benign cases from the initial series who underwent repeat biopsy}

In the initial series, 15 patients required repeat biopsy, four of them because were diagnosed as ASAP by HE. Three (20\%) of the 15 cases were diagnosed as adenocarcinoma on second biopsy and one (33.3\%) of three cases as adenocarcinoma on third biopsy. The results for the first, second, and third biopsies are shown in Table 2.

\section{Malignant cases (minimal adenocarcinoma) tested by IHC}

IHC was performed in seven (3.15\%) of 222 cases diagnosed as adenocarcinoma because of the small size

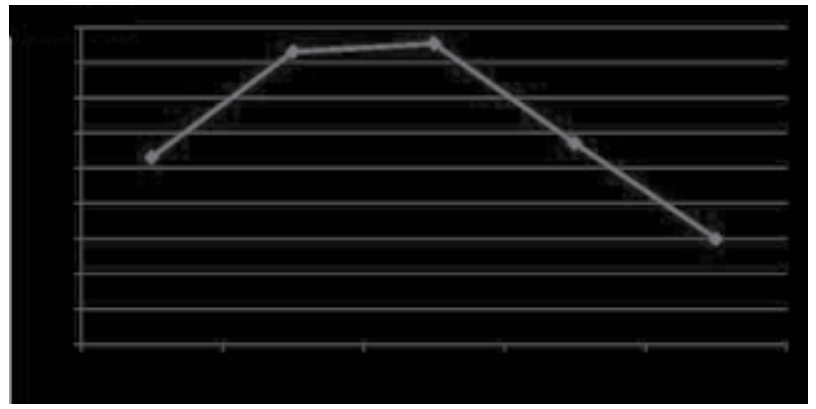

Figure 2 - Percentage of ASAP diagnosis per year from prostate biopsies performed by a public laboratory of pathology

ASAP: atypical small acinar proliferation.

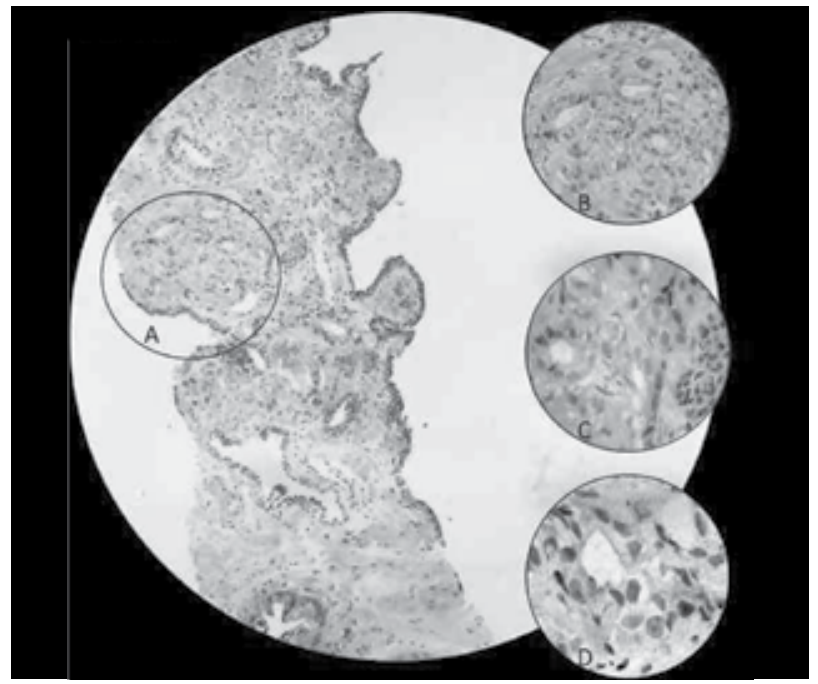

Figure $3-A S A P$

(A) HE, 40x; (B) HE, 100x; (C) HE, 400x; (D) absence of basal cell layers, as assessed by immunostaining using $34 \beta E 12+p 63$ confirms the diagnosis of adenocarcinoma.

ASAP: atypical small acinar proliferation; HE: hematoxylin and eosin.

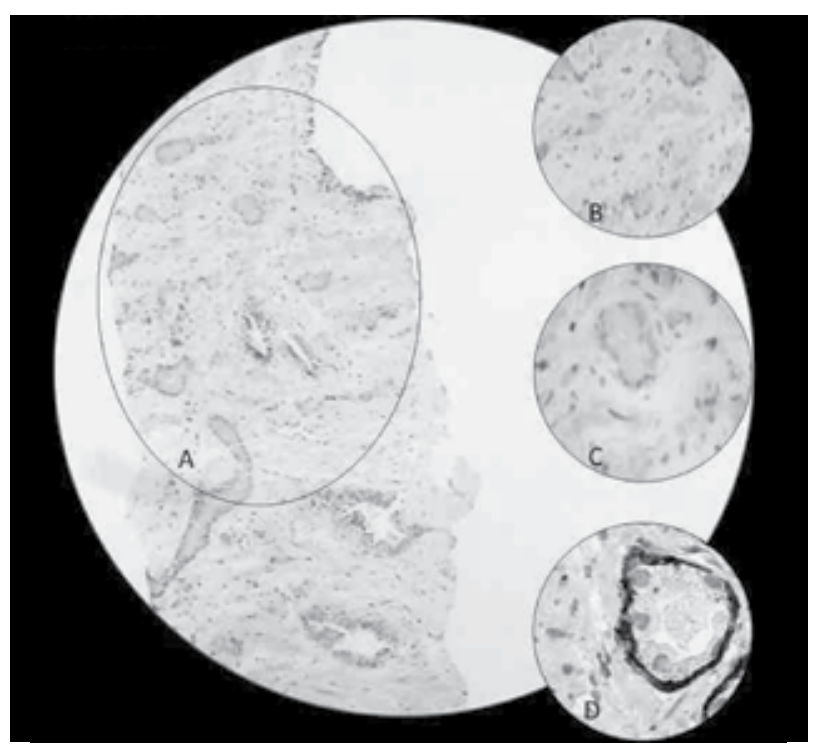

Figure $4-A S A P$

(A) HE, 40x; (B) HE, 100x; (C) HE, 400x; (D) immunostaining using a basal cell antibody cocktail (34ßE12 + p63) confirms the absence of cancer. ASAP: atypical small acinar proliferation; HE: hematoxylin and eosin. 


\begin{tabular}{|c|c|c|c|c|}
\hline \multirow[b]{2}{*}{ Patient } & \multicolumn{4}{|c|}{$\begin{array}{l}\text { Evaluation of cases diagnosed as ASAP } \\
\text { in the initial series, who underwent IHC } \\
\text { analysis and/or IHC and repeat biopsy }\end{array}$} \\
\hline & $\begin{array}{l}\text { Biopsy } \\
\text { (HE) }\end{array}$ & $\mathrm{IHC}$ & $\begin{array}{l}\text { Repeat } \\
\text { biopsy }\end{array}$ & $\begin{array}{c}\text { Gleason } \\
\text { score }\end{array}$ \\
\hline 1 & ASAP & Malignant & No & $6(3+3)$ \\
\hline 2 & ASAP & Malignant & No & $6(3+3)$ \\
\hline 3 & ASAP & Malignant & No & $6(3+3)$ \\
\hline 4 & ASAP & Malignant & No & $6(3+3)$ \\
\hline 5 & ASAP & Malignant & No & $6(3+3)$ \\
\hline 6 & ASAP & Malignant & No & $6(3+3)$ \\
\hline 7 & ASAP & Malignant & No & $6(3+3)$ \\
\hline 8 & ASAP & Malignant & No & $6(3+3)$ \\
\hline 9 & ASAP & Malignant & No & $6(3+3)$ \\
\hline 10 & ASAP & Malignant & No & $6(3+3)$ \\
\hline 11 & ASAP & Malignant & No & $6(3+3)$ \\
\hline 12 & ASAP & Malignant & No & $6(3+3)$ \\
\hline 13 & ASAP & Malignant & No & $6(3+3)$ \\
\hline 14 & ASAP & Malignant & No & $6(3+3)$ \\
\hline 15 & ASAP & Malignant & No & $6(3+3)$ \\
\hline 16 & ASAP & Malignant & No & $6(3+3)$ \\
\hline 17 & ASAP & Malignant & No & $6(3+3)$ \\
\hline 18 & ASAP & Malignant & No & $6(3+3)$ \\
\hline 19 & ASAP & Malignant & No & $8(4+4)$ \\
\hline 20 & ASAP & Benign & No & - \\
\hline 21 & ASAP & Benign & No & - \\
\hline 22 & ASAP & Benign & No & - \\
\hline 23 & ASAP & Benign & No & - \\
\hline 24 & ASAP & Benign & No & - \\
\hline 25 & ASAP & Benign & No & - \\
\hline 26 & ASAP & Benign & No & - \\
\hline 27 & ASAP & Benign & No & - \\
\hline 28 & ASAP & Benign & No & - \\
\hline 29 & ASAP & Benign & No & - \\
\hline 30 & ASAP & Benign & No & - \\
\hline 31 & ASAP & ASAP & No & - \\
\hline 32 & ASAP & ASAP & No & - \\
\hline 33 & ASAP & ASAP & No & - \\
\hline 34 & ASAP & Benign & Benign & - \\
\hline 35 & ASAP & ASAP & ASAP & - \\
\hline
\end{tabular}

ASAP: atypical small acinar proliferation; IHC: immunohistochemistry; $H E$ : hematoxylin and eosin.

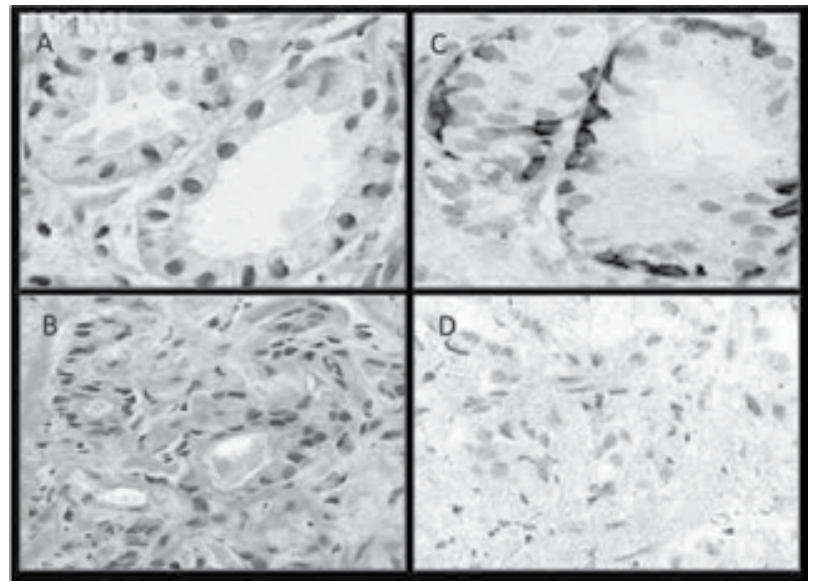

Figure 5 - ASAP

(A) ASAP; (B) ASAP; (C) immunostaining using a basal cell antibody cocktail (34 $\beta E 12+p 63)$ rules out cancer; (D) absence of basal cell layers, as assessed by immunostaining using $34 \beta E 12+p 63$ confirms the diagnosis of adenocarcinoma. ASAP: atypical small acinar proliferation.

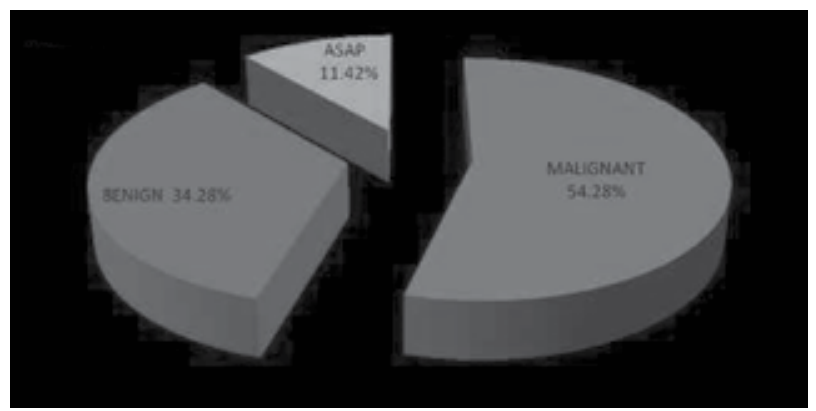

Figure 6 - Final diagnosis by IHC of cases diagnosed as ASAP in the initial series $(n=35)$

IHC: immunohistochemistry; ASAP: atypical small acinar proliferation.

of the tumors (tumors $<1 \mathrm{~mm}$ in greatest dimension or cancer involving $<5 \%$ of needle core tissue). Diagnosis of malignancy was confirmed in all seven cases. The Gleason score was $3+3=6$ for five tumors and $4+4=8$ for two minimal adenocarcinomas.

\section{Comparisons of IHC and repeat biopsy results with ASAP diagnosis in the initial series}

A conclusive diagnosis was reached for 39 cases with ASAP diagnosis in the initial series ( 33 by IHC, four by repeat biopsy, and two by IHC and repeat biopsy), as shown in Table 3. A diagnosis was considered conclusive when benign or malignant lesions were detected; ASAP cases were considered inconclusive results.

\section{Discussion}

The results of this study are important because they derived from two laboratories of surgical pathology, one 
private and one public, which provide diagnostic services for a population of several cities in the region, but are not reference laboratories.

There are many important procedures for prostate carcinoma screening, including digital rectal examination,

\begin{tabular}{|c|c|c|c|}
\hline \multirow{2}{*}{$\frac{\text { Table } 2}{\text { Pacient }}$} & \multicolumn{3}{|c|}{$\begin{array}{l}\text { Evaluation of ASAP and benign cases } \\
\text { diagnosed the initial series, subjected to } \\
\text { repeat biopsy }\end{array}$} \\
\hline & $1^{\text {st }}$ biopsy & $2^{\text {nd }}$ biopsy & $3^{\text {rd }}$ biopsy \\
\hline 1 & Benign & Benign & $\begin{array}{l}\text { Malignant - } \\
\text { Gleason } \\
3+3=6\end{array}$ \\
\hline 2 & Benign & Benign & Benign \\
\hline 3 & Benign & Benign & Benign \\
\hline 4 & Benign & $\begin{array}{l}\text { Malignant - } \\
\text { Gleason } \\
3+4=7\end{array}$ & - \\
\hline 5 & Benign & Benign & - \\
\hline 6 & Benign & Benign & - \\
\hline 7 & Benign & Benign & - \\
\hline 8 & Benign & Benign & - \\
\hline 9 & Benign & Benign & - \\
\hline 10 & Benign & Benign & - \\
\hline 11 & Benign & Benign & - \\
\hline 12 & ASAP & Benign & - \\
\hline 13 & ASAP & Benign & - \\
\hline 14 & ASAP & $\begin{array}{l}\text { Malignant - } \\
\text { Gleason } \\
3+3=6\end{array}$ & - \\
\hline 15 & ASAP & $\begin{array}{l}\text { Malignant - } \\
\text { Gleason } \\
5+5=10\end{array}$ & - \\
\hline
\end{tabular}

ASAP: atypical small acinar proliferation. ultrasound examination, and PSA-based screening, but the final diagnosis is made by histopathology based on well-established criteria, such as architectural disarray and cytologic features. At present, early detection efforts have resulted in the detection of minimal adenocarcinoma of the prostate. This makes it difficult for the pathologist to classify lesions too small or poorly defined histologically ${ }^{(7)}$. Most tumors are detected on first biopsy, but in some cases the pathologist cannot diagnose adenocarcinoma by histological examination.

ASAP refers to minute tumor foci, a small lesion that may not be detectable in other sections of the prostate biopsy or is insufficient evidence for the diagnosis of carcinoma. There is no consensus on the use of ASAP as a diagnostic category; in fact, it represents a lesion hardly detectable by biopsy or one of the many benign lesions that mimic cancer. Some authors have used the diagnostic term "foci of atypical glands" to refer to atypical small acinar proliferation containing inconclusive morphological features for the diagnosis of carcinoma ${ }^{(16)}$. In order to elucidate inconclusive diagnoses, repeat biopsy or the use of IHC may be required.

It is important to note that the diagnosis of adenocarcinoma is based on histological examination and that IHC plays an auxiliary role. Absence of basal cells is not specific to prostate carcinoma; mesonephric hyperplasia, nephrogenic adenoma, benign prostatic glands may also show absence of basal cells, especially atrophic glands. Lack of basal cell staining in more than two benign glands occurred in $23 \%$ (25/108) and $9 \%(10 / 108)$ of prostate needle biopsies cores stained with $34 \beta E 12$ and $\mathrm{p} 63$, respectively ${ }^{(27)}$.

Conversely, aberrant expression of $p 63$ and $34 \beta E 12$ has been described in prostatic adenocarcinoma, which may lead to erroneous diagnosis ${ }^{(24)}$. Negative staining for basal cells supports the diagnosis of adenocarcinoma, but a malignant diagnosis should be established based on morphology using hematoxylin and eosin staining.

\begin{tabular}{|c|c|c|c|c|}
\hline ble 3 ASAP c & results of IHC & t biopsies for $t$ & lusive diagnosis of ad & carcinoma in \\
\hline \multirow[t]{2}{*}{ Diagnosis } & \multicolumn{3}{|c|}{ Procedure } & \multirow[t]{2}{*}{ Total $(n)$} \\
\hline & IHC & Repeat biopsy & IHC and repeat biopsy & \\
\hline Adenocarcinoma & 19 (57.58\%) & $2(50 \%)$ & $0(0 \%)$ & 21 \\
\hline Benign & $11(36.36 \%)$ & $2(50 \%)$ & $1(50 \%)$ & 14 \\
\hline ASAP & $3(6.06 \%)$ & $0(0 \%)$ & $1(50 \%)$ & 4 \\
\hline Total $(n)$ & 33 & 4 & 2 & 39 \\
\hline
\end{tabular}

IHC: immunohistochemistry; ASAP: atypical small acinar proliferation. 
Epstein and Herawi ${ }^{(5)}$ reported that an average of 5\% (range, $0.7 \%-23.4 \%$ ) of needle biopsy pathology reports are diagnosed as ASAP. In the present study, the incidence de ASAP was $11.38 \%$. The percentage of ASAP cases was $12.15 \%$ in the public laboratory and $10.73 \%$ in the private laboratory. The annual prevalence of ASAP cases in the public laboratory showed a decrease in the percentage of inconclusive diagnoses in the past two years, possibly reflecting an increased ability of the team of pathologists to render an accurate diagnosis.

IHC was performed in 35 of the 73 ASAP cases and provided conclusive results in 31 cases (88.57\%). From the 19 cases with a final diagnosis of adenocarcinoma, 18 had a Gleason score $3+3=6$ and one had a Gleason score $4+$ $4=8$, indicating that most tumors had an intermediate grade of malignancy. Previous studies have identified adenocarcinomas with different grades of malignancy (Gleason score 5-6, 18\%-71\%; Gleason score $\geq 7,19 \%-82 \%$ ) on follow-up biopsies obtained from patients with a previous ASAP diagnosis ${ }^{(13,21,25)}$.

Studies have shown that $\mathrm{IHC}$ is useful in confirming benignity because it may show the presence or absence of the basal cell layer. This is in agreement with the findings of Wojno and Epstein ${ }^{(30)}$, who performed a review of 228 ASAP cases and reported that only $18 \%$ of cases remained inconclusive after being assessed by IHC using $34 \beta \mathrm{E} 12$ antibody. In that study, the main reason for equivocal results was loss of suspicious glands on sections used for staining.

Many laboratories of surgical pathology use the interval workup on selected cases to prevent this problem. The workup consists of performing IHC analysis on unstained interval sections that are routinely saved using the antibody cocktail for p63, cytokeratins 5 and 14, and $\alpha$-ethylacyl CoA racemase $^{(9,28)}$. From 1,105 prostate needle biopsy cases seen at Johns Hopkins, IHC staining for high molecular weight cytokeratin was initially done on 94 (8.5\%). In order to see whether lesions would still have been present for evaluation in the absence of intervening slides, $\mathrm{IHC}$ was repeated for IHC off the paraffin blocks in 74 cases for which material was available for study. In 52 cases, the original IHC helped to establish a diagnosis; in 31 of these cases the lesion was not present on repeat IHC stains from the block. Of these 31 cases, the original IHC from intervening unstained slides helped to establish cancer $(n=23)$ or a benign $(n=8)$ diagnosis. The use of intervening unstained slides was critical to establish a diagnosis in $31(2.8 \%)$ of 1,105 prostate needle biopsies and saved the cost of repeat biopsy $(\$ 68,200)$ and spared these patients from a second surgical procedure ${ }^{(9)}$.
The number of biopsies needed to detect prostate cancer is controversial. When there is a strong clinical suspicion of malignancy and the first biopsy is negative, repeat biopsy should be performed ${ }^{(18)}$. Most tumors are detected on first biopsy, but $15 \%$ to $30 \%$ of prostate cancers are diagnosed by repeat biopsy if there are predictive factors for positive results, such as PSA velocity $>0.75 \mathrm{ng} / \mathrm{ml} /$ year, high-grade prostate intraepithelial neoplasia (PIN) or ASAP on first biopsy.

An ASAP diagnosis increases the possibility of diagnosing cancer in a subsequent biopsy ${ }^{(5,16,26)}$. Cheville et al. ${ }^{(2)}$ reviewed 1,009 prostate biopsies and determined an incidence of ASAP cases of $5.5 \% ; 45 \%$ of patients with an initial diagnosis of ASAP underwent repeat biopsy and in $60 \%$ of them the diagnosis of adenocarcinoma was confirmed.

In another study, Iczkowski et al. ${ }^{(13)}$ evaluated 295 patients with ASAP diagnosis on the first prostate biopsy. Adenocarcinoma was confirmed in $42 \%$ of cases on second biopsy. The tumor was present at the same location as found in the first biopsy (initial ASAP diagnosis) in $56 \%$ of cases, and in $27 \%$ the lesion was identified in the contralateral side of the prostate. In the second biopsy, no histological findings including serum PSA levels, number of acini per focus of ASAP, and nuclear grade were predictive of increased cancer risk ${ }^{(13)}$.

Mancuso et al.(21), in a series of 31 patients with an initial diagnosis of ASAP, found that 22 had at least one repeat biopsy. The incidence of prostate adenocarcinoma in this group was $55 \%(17 / 31)$, including 13 diagnosis of adenocarcinoma on second biopsy, and three on third biopsy (one biopsy was processed at another institution). The study showed a detection rate for prostate adenocarcinoma of $55 \%$ after an initial diagnosis of ASAP, indicating that repeat biopsy should be performed as soon as possible in these cases.

From the 641 cases in our initial series, 15 met criteria for repeat biopsy, four of them because of an initial ASAP diagnosis. Only three (20\%) of the 15 cases were diagnosed with adenocarcinoma on second biopsy and one of three cases $(33.3 \%)$ on third biopsy, possibly because of IHC analysis, which allows a more conclusive diagnosis. The indication for third and fourth biopsies depends on clinical suspicion and predictive factors; the detection of prostate cancer has been confirmed in about $5 \%$ of these cases.

A recent study on radical prostatectomy specimens in men undergoing treatment for adenocarcinoma, which required the use of IHC for final diagnosis, showed no 
overdiagnosis of prostate carcinoma in patients with pT0 after radical prostatectomy. Only $7.4 \%$ of cases were classified as "clinically insignificant", which is defined as less than $2 \%$ of gland involvement, organ-confined disease, and without Gleason 4 or 5 pattern. In that series, all patients had palpable tumors (stages pT2 and pT3) ${ }^{(17)}$.

On the one hand, efforts for early detection of prostate cancer have found a majority of patients with localized disease and better prognosis, and on the other hand, have resulted in radical prostatectomy specimens with extremely small tumors or no residual tumor ${ }^{(3)}$. This was classified by Goldstein et al.(9) in 1995, as minimal residual cancer or "vanishing cancer phenomenon"; its annual incidence increased from $0.5 \%$ in 1988 to $4 \%$ in 1993 . Tumors diagnosed in prostate biopsies indicated by elevated PSA levels but which are not detectable by ultrasound or digital rectal examination (T1c stage) have a $75 \%{ }^{(23)}$ to $94 \%{ }^{(6)}$ probability of having a volume $<0.5 \mathrm{cc}$, and in about $2.5 \%$ of cases they are not found in the surgical specimen ${ }^{(8)}$.

The increased incidence of minimal residual cancer in radical prostatectomy after positive biopsy (T0) may have ethical and legal implications. One of the major diagnostic challenges confronting the histopathologist in the interpretation of a prostate needle biopsy specimen is the establishment of a malignant diagnosis based on a minimal or limited amount of carcinoma in the needle biopsy tissue. Minimal carcinoma in needle biopsy tissue is defined as a tumor with a size $<1 \mathrm{~mm}$ in greatest dimension ${ }^{(29)}$. Another definition of minimal adenocarcinoma is cancer involving $<5 \%$ of needle core tissue ${ }^{(12)}$. The major and minor diagnostic criteria should be used for more extensive carcinoma. At present, there has been a growing trend to use IHC to confirm the diagnosis of minimal adenocarcinoma ${ }^{(11,15,19)}$. In this study, IHC was also performed in seven (3.15\%) of 222 cases diagnosed as adenocarcinoma because of the small size of the tumor and in $100 \%$ of cases a conclusive diagnosis was reached.

Our results suggest that IHC should be routinely used in borderline biopsies and ASAP cases. The final diagnosis of adenocarcinoma in 19 patients (54.28\%) with an initial ASAP diagnosis, preventing repeat biopsies and their possible complications, supports the importance of IHC in the diagnosis of prostate cancer in prostate needle biopsies.

\section{References}

1. CHENG, L. et al. Prostatic intraepithelial neoplasia: an update. Clin Prostate Cancer, v. 1, n. 3, p. 26-30, 2004.

2. CHEVILLE, J. C. et al. The focus of atypical glands, suspicious for malignancy in prostatic needle biopsy specimens: incidence, histologic features, and clinical follow-up of cases diagnosed in a community practice. Am J Clin Pathol, v. 108, n. 6, p. 633-40, 1997.

3. DIGIUSEPPE, J. A. et al. Increasing incidence of minimal residual cancer in radical prostatectomy specimens. Am J Surg Pathol, v. 21, n. 2, p. 174-8, 1997.

4. DJAVAN, B. et al. Prospective evaluation of prostate cancer detected on biopsies 1, 2, 3 and 4; when should we stop? J Urol, v. 166, n. 5, p. 1679-83, 2001.

5. EPSTEIN, J. I.; HERAWI, M. Prostate needle biopsies containing prostatic intraepithelial neoplasia or atypical foci suspicious for carcinoma: implications for patient care. J Urol, v. 175, n. 3 (Pt. 1), p. 820-34, 2006.

6. EPSTEIN, J. I. et al. Nonpalpable stage T1c prostate cancer: prediction of insignificant disease using free/ total prostate specific antigen levels and needle biopsy findings. J Urol, v. 160, n. 6 (Pt. 2), p. 2407-11, 1998.

7. EPSTEIN, J. I. et al. The pathological interpretation and significance of prostate needle biopsy findings: implications and current controversies. J Urol, v. 166, n. 2, p. 402, 2001.

8. GILCREASE, M. Z. Minimal residual cancer. Am J Surg Pathol, v. 21, n. 12, p. 1524-5, 1997.
9. GOLDSTEIN, N. S. et al. Minimal or no cancer in radical prostatectomy specimens. Report of 13 cases of the vanishing cancer phenomenon. Am J Surg Pathol, v. 19, n. 9, p. 1002-9, 1995.

10. GREEN, R.; EPSTEIN, J. I. Use of intervening unstained slides for immunohistochemical stains for high molecular weight cytokeratin on prostate needle biopsies. Am J Surg Pathol, v. 23, n. 5, p. 567-70, 1999.

11. HUMPHREY, P. A. Diagnosis of adenocarcinoma in prostate needle biopsy tissue. J Clin Pathol, v. 60, n. 1, p. 35-42, 2007.

12. ICZKOWSKI, K. A.; BOSTWICK, D. G. Criteria for biopsy diagnosis of minimal volume prostatic adenocarcinoma: analytic comparison with nondiagnostic but suspicious atypical small acinar proliferation. Arch Pathol Lab Med, v. 124, n. 1, p. 98-107, 2000.

13. ICZKOWSKI, K. A. et al. Diagnosis of suspicious for malignancy in prostate biopsies: predictive value for cancer. Urology, v. 51, n. 5, p. 749-58, 1998.

14. ICZKOWSKI, K. A.; MACLENNAN, G. T. Atypical small acinar proliferation suspicious for malignancy in prostate needle biopsies. Am J Surg Pathol, v. 21, n. 12, p. 1489-95, 1997.

15. JIANG, Z. et al. P504S/alpha-methylacyl-CoA racemase. A useful marker for diagnosis of small foci of prostatic carcinoma on needle biopsy. Am J Surg Pathol, v. 26, n. 9, p. 1169-74, 2002. 
16. LEITE, K. R.; MITTELDORF, C. A.; CAMARA-LOPES, L. H. Repeat prostate biopsies following diagnoses of prostate intraepithelial neoplasia and atypical small gland proliferation. Int Braz J Urol, v. 31, n. 2, p. 131-6, 2005.

17. LEITE, K. R. et al. The use of immunohistochemistry for diagnosis of prostate cancer. Int Braz J Urol, v. 36, n. 5, p. 583-90, 2010.

18. LOPEZ-CORONA, E. et al. A nomogram for predicting a positive repeat prostate biopsy in patients with a previous negative biopsy session. J Urol, v. 170, n. 4 (Pt. 1), p. 1184-8, 2003.

19. MAGI-GALLUZZI, C. et al. Alpha-methylacyl-CoA racemase: a variably sensitive immunohistochemical marker for the diagnosis of small cancer foci on needle biopsy. Am J Surg Pathol, v. 27, n. 8, p. 1128-33, 2003.

20. MAJJED, A. et al. Trends in prostate cancer incidence, mortality e survival in England and Wales 1971-1990. BJU Int, v. 85, n. 9, p. 1058-62, 2000.

21. MANCUSO, P. A. et al. Prostate cancer detection in men with an initial diagnosis of atypical small acinar proliferation. BJU Int, v. 99, n. 1, p. 49-52, 2007.

22. MOLINIE, V. et al. Value of the antibody cocktail anti p53 + anti p504s for the diagnosis of the prostatic cancer. Ann Pathol, v. 24, n. 1, p. 6-16, 2004.

23. NOGUCHI, M. et al. Relationship between systematic biopsies and histological features of 222 radical prostatectomy specimens: lack of prediction of tumor significance for men with nonpalpable prostate cancer. J Urol, v. 166, n. 1, p. 104-9, 2001.

24. OSUNKOYA, A. O. et al. Aberrant diffuse expression of p63 in adenocarcinoma of the prostate on needle biopsy and radical prostatectomy: report of 21 cases. Am J Surg Pathol, v. 32, n. 3, p. 461-7, 2008.
25. PARK, S. et al. Prostate cancer detection in men with prior high grade prostatic intraepithelial neoplasia or atypical prostate biopsy. J Urol, v. 165, n. 5, p. 1409-14, 2001.

26. SCHLESINGER, C.; BOSTWICK, D. G.; ICZKOWSKI, K. A High-grade prostatic intraepithelial neoplasia and atypical small acinar proliferation: predictive value for cancer in current practice. Am J Surg Pathol, v. 29, n. 9, p. 1201-7, 2005. Erratum in: Am J Surg Pathol, v. 29, n. 11, p. 1548, 2005.

27. SHAH, R. et al. Comparison of basal cell-specific markers, 34betaE12 and p63, in the diagnosis of prostate cancer. Am J Surg Pathol, v. 26, n. 9, p. 1161-8, 2002.

28. STRAND, C. L. et al. Improved resolution of diagnostic problems in selected prostate needle biopsy specimens by using the ASAP workup: a prospective study of interval sections vs new recut sections. Am J Clin Pathol, v. 134, n. 2, p. 293-8, 2010.

29. THORSON, P. et al. Minimal carcinoma in prostate needle biopsy specimens: diagnostic features and radical prostatectomy follow-up. Mod Pathol, v. 11, n. 6, p. 543-51, 1988.

30. WOJNO, K. J; EPSTEIN, J. I. The utility of basal cell-specific anti-cytokeratin antibody (34 beta E12) in the diagnosis of prostate cancer. A review of 228 cases. Am J Surg Pathol, v. 19, n. 3, p. 251-60, 1995.

31. ZHOU, M. et al. Basal cell cocktail (34betaE12 + p63) improves the detection of prostate basal cells. Am J Surg Pathol, v. 27. n. 3, p. 365-71, 2003.

32. ZHOU, M. et al. Comparison of the basal cell-specific markers, 34 betaE12 and p63, in the diagnosis of prostate cancer. Am J Surg Pathol, v. 26, n. 9, p. 1161-8, 2002. 